\title{
ЛИТОЛОГИЯ
}

УДК 550.42

\section{К сопоставлению валового химического состава глинистых пород нижней перми Юрюзано-Сылвинской и Бельской впадин}

\author{
Г.А. Мизенс, А.В. Маслов \\ Институт геологии и геохимии УрО РАН им. акад. А.Н. Заварицкого, \\ 620075, Екатеринбург, Почтовый пер., 7. E-mails: mizens@igg.uran.ru, \\ maslov@igg.uran.ru \\ (Статья поступила в редакцию 2 апреля 2014 г.)
}

В результате анализа литогеохимических особенностей глинистых пород нижней перми Бельской и Юрюзано-Сылвинской впадин Предуральского прогиба установлено отсутствие принципиальных различий между ними, что может свидетельствовать об общем источнике сноса. В целом валовый химический состав глинистых пород нижней перми Предуральского прогиба сопоставим с PAAS по содержаниям $\mathrm{SiO}_{2}, \mathrm{TiO}_{2}, \mathrm{Al}_{2} \mathrm{O}_{3}, \mathrm{FeO}_{\text {общ, }} \mathrm{K}_{2} \mathrm{O}$ и $\mathrm{P}_{2} \mathrm{O}_{5}$, некоторое отличие наблюдается лишь по $\mathrm{MgO}, \mathrm{CaO}$ и $\mathrm{Na}_{2} \mathrm{O}$. Содержания $\mathrm{Cr}, \mathrm{Co}, \mathrm{Ni}$ и $\mathrm{Zn}$ в большинстве образцов аргиллитов Бельской впадины выше, чем ЮрюзаноСылвинской впадины, в то же время для аргиллитов из бассейна р. Уфы характерны несколько более высокие концентрации $\mathrm{Sc}, \mathrm{Sr}, \mathrm{Y}, \mathrm{Mo} \mathrm{и} \mathrm{РЗЭ.} \mathrm{Распределе-}$ ние РЗЭ в аргиллитах обеих впадин сопоставимо. Общая обедненность их, относительно PAAS, легкими лантаноидами, а также слабо выраженная положительная Еu аномалия предполагают присутствие в составе пород существенной доли продуктов размыва основных магматических образований.

Ключевые слова: Юрюзано-Сылвинская впадина, Бельская впадина, глинистые породы, нижняя пермь, валовый химический состав, распределение редких и рассеянных элементов.

Предуральский прогиб представляет собой неоднородную структуру, строение которой, как и состав выполняющих ее обломочных формаций, связано в первую очередь с особенностями формирования палеозойского Уральского орогена. Изучение обломочных комплексов прогиба ведется уже много лет, однако попрежнему остаются неясными вопросы, в том числе относящиеся к источникам вещества. Уточнению некоторых из них может способствовать анализ химическо- го состава глинистых образований, сохранивших тонкие и неустойчивые компоненты пород области сноса.

Рассматриваемый прогиб, как известно, сначала существовал в виде цепочки из нескольких разобщенных впадин. Только к артинскому веку он стал единым [1]. Во второй половине карбона в южной части прогиба сформировались три глубоководные впадины - ЮрюзаноСылвинская, Бельская и Актюбинская. Причем две первые были разделены ши- 
роким поднятием в области современного Башкирского мегантиклинория. Как и в других случаях, перемычка между этими впадинами исчезла в артинском веке, когда прогиб несколько сместился на запад. Для того чтобы уточнить особенности источников сноса во время, когда впадины были разобщенными и когда прогиб стал единым, был проанализирован химиче- ский состав глинистых пород по трем профилям (разрезам) - вдоль долины р. Уфы на широте г. Михайловска, на р. Юрюзани выше пос. Малояз и по р. Белой в широтном отрезке долины у д. Сырять. Два первых профиля относятся к Юрюзано-Сылвинской впадине, третий - к Бельской (рис. 1).

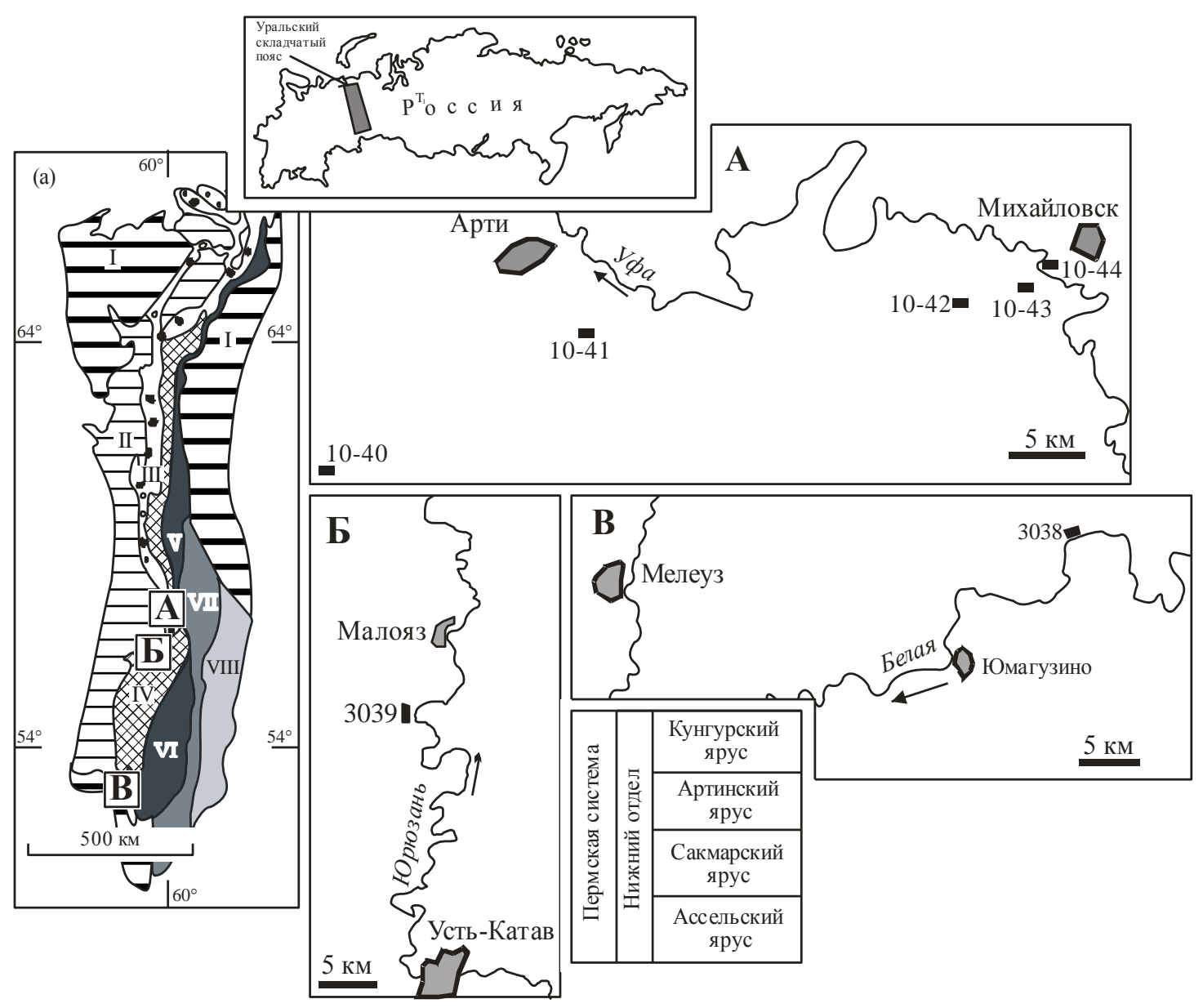

Рис. 1. Схемы расположения исследованных обнажений нижней перми в Юрюзано-Сылвинской ( $A$ - бассейн р. Уфы, Б-на р. Юрюзани) и Бельской (B - на р. Белой) впадинах: I-мезозойскокайнозойские отложения; II - Предуральский прогиб; III-VIII - мегазоны: III - ЗападноУральская, IV - Центрально-Уральская, V-Тагильская, VI - Магнитогорская, VII - ВосточноУральская, VIII - Зауральская

По петрографическому составу песчаников все три района несколько различаются. Меняется состав этих пород и вверх по разрезу. Так, по р. Уфе в нижней части пермского интервала (ассельский и сакмарский ярусы) распространены кварцполевошпатовые граувакки (по классификации В.Д. Шутова), с высоким содержа-

нием обломков пород, среди которых преобладают силициты, а количество кислых и основных вулканитов примерно равное. В артинских и кунгурских песчаниках несколько увеличивается количество зерен кварца, граувакки становятся полевошпато-кварцевыми, а среди обломков пород чаще встречаются вулканиты. 
Таблица 1. Средние, минимальнье и максимальные содержания основных породообразующих оксидов в алевритоглинистьх породах нижней перми

\begin{tabular}{|c|c|c|c|c|c|c|c|}
\hline \multirow{3}{*}{$\begin{array}{c}\text { Компоненты, } \\
\text { мас. \% }\end{array}$} & \multicolumn{2}{|c|}{ Юрюзано-Сылвинская впадина } & \multirow{2}{*}{$\begin{array}{c}\begin{array}{c}\text { Бельская впа- } \\
\text { дина }\end{array} \\
\text { р. Белая }\end{array}$} & \multirow{2}{*}{$\begin{array}{c}\text { Юрюзано- } \\
\text { Сылвинская вІ. } \\
\text { р. Уфа }\end{array}$} & \multirow{2}{*}{$\begin{array}{c}\begin{array}{c}\text { Бельская впа- } \\
\text { дина }\end{array} \\
\text { р. Белая }\end{array}$} & \multicolumn{2}{|c|}{ Юрюзано-Сылвинская впадина } \\
\hline & р. Юрюзань & p. Уфа & & & & p. Уфа & p. Уфа \\
\hline & \multicolumn{2}{|c|}{ Ассельский ярус } & \multicolumn{2}{|c|}{ Сакмарский ярус } & \multicolumn{2}{|c|}{ Артинский ярус } & Кунгурский ярус \\
\hline $\mathrm{SiO}_{2}$ & $\frac{53,71 \pm 2,92}{49,41-57,43}$ & $\frac{42,54 \pm 11,34}{26,52-50,42}$ & 48,61 & $\frac{48,85 \pm 1,91}{45,40-50,73}$ & $\frac{51,32 \pm 2,01}{48,76-55,07}$ & $\frac{50,35 \pm 3,82}{47,54-56,58}$ & $\frac{52,33 \pm 1,18}{50,26-53,80}$ \\
\hline $\mathrm{TiO}_{2}$ & $\underline{0,70 \pm 0,08}$ & $\underline{0,48 \pm 0,22}$ & \multirow{2}{*}{0,64} & $\underline{0,61 \pm 0,08}$ & $\underline{0,54 \pm 0,09}$ & $\underline{0,49 \pm 0,06}$ & $\underline{0,64 \pm 0,08}$ \\
\hline & $\overline{0,55-0,79}$ & $\overline{0,18-0,64}$ & & $\overline{0,50-0,77}$ & $\overline{0,44-0,74}$ & $\overline{0,39-0,58}$ & $\overline{0,55-0,77}$ \\
\hline $\mathrm{Al}_{2} \mathrm{O}_{3}$ & $\underline{10,78 \pm 1,06}$ & $\underline{9,69 \pm 2,95}$ & \multirow{2}{*}{11,37} & $\underline{11,24 \pm 0,80}$ & $\underline{10,18 \pm 0,95}$ & $\underline{10,64 \pm 1,02}$ & $\underline{13,11 \pm 0,88}$ \\
\hline & $8,42-11,78$ & $5,42-12,19$ & & $9,86-12,22$ & $8,91-11,93$ & $8,69-11,68$ & $12,17-14,66$ \\
\hline $\mathrm{Fe}_{2} \mathrm{O}_{3 \text { общ. }}$ & $\underline{7,28 \pm 1,54}$ & $\underline{6,22 \pm 2,75}$ & \multirow{2}{*}{8,19} & $\underline{6,19 \pm 1,05}$ & $\underline{6,12 \pm 1,32}$ & $\underline{4,91 \pm 0,54}$ & $\underline{7,15 \pm 1,30}$ \\
\hline & $\overline{4,38-9,01}$ & $\overline{2,62-8,34}$ & & $4,60-8,05$ & $\overline{5,12-9,48}$ & $4,19-5,51$ & $5,54-9,29$ \\
\hline $\mathrm{MgO}$ & $\underline{7,25 \pm 1,78}$ & $\underline{3,74 \pm 0,69}$ & \multirow{2}{*}{7,66} & $\underline{3,01 \pm 0,37}$ & $\underline{6,78 \pm 1,75}$ & $2,93 \pm 0.15$ & $4,64 \pm 0,37$ \\
\hline & $\overline{4,12-9,54}$ & $\overline{2,72-4,42}$ & & $\overline{2,46-3,77}$ & $\overline{4,57-9,32}$ & $\overline{2,75-3,15}$ & $\overline{4,12-5,34}$ \\
\hline $\mathrm{CaO}$ & $\underline{6,21 \pm 2,59}$ & $\underline{15,17 \pm 10,46}$ & \multirow{2}{*}{6,96} & $\underline{11,09 \pm 2,42}$ & $\underline{8,63 \pm 2,05}$ & $\underline{11,64 \pm 1,35}$ & $\underline{6,14 \pm 2,46}$ \\
\hline & $\overline{3,78-11,48}$ & $\overline{7,87-29,57}$ & & $\overline{6,81-15,08}$ & $\overline{3,93-10,80}$ & $\overline{9,37-12,99}$ & $\overline{1,96-8,89}$ \\
\hline $\mathrm{MnO}$ & $\underline{0,15 \pm 0,06}$ & $0,12 \pm 0,05$ & \multirow{2}{*}{0,08} & $\underline{0,06 \pm 0,02}$ & $\underline{0,08}$ & $\underline{0,06 \pm 0,01}$ & $\underline{0,06 \pm 0,01}$ \\
\hline & $\overline{0,10-0,23}$ & $\overline{0,07-0,20}$ & & $\overline{0,04-0,10}$ & $0,0 \overline{8-0,09}$ & $\overline{0,05-0,09}$ & $\overline{0,05-0,07}$ \\
\hline $\mathrm{K}_{2} \mathrm{O}$ & $\underline{1,90 \pm 0,29}$ & $\underline{1,52 \pm 0,56}$ & \multirow{2}{*}{2,61} & $\underline{1,69 \pm 0,10}$ & $\underline{1,72 \pm 0,40}$ & $2,03 \pm 0,36$ & $2,52 \pm 0,13$ \\
\hline & $\overline{1,37-2,21}$ & $\overline{0,75-2,07}$ & & $\overline{1,55-1,79}$ & $\overline{1,33-2,38}$ & $\overline{1,37-2,34}$ & $\overline{2,37-2,75}$ \\
\hline $\mathrm{Na}_{2} \mathrm{O}$ & $\underline{1,39 \pm 0,33}$ & $\underline{1,58 \pm 0,29}$ & \multirow{2}{*}{2,25} & $\underline{1,96 \pm 0,43}$ & $\underline{1,92 \pm 0,78}$ & $\underline{1,53 \pm 0,44}$ & $\underline{1,84 \pm 0,60}$ \\
\hline & $1,00-2,00$ & $1,10-1,90$ & & $1,60-3,00$ & $0,97-3,70$ & $1,10-2,30$ & $1,50-3,20$ \\
\hline $\mathrm{P}_{2} \mathrm{O}_{5}$ & $\underline{0,17 \pm 0,02}$ & $\underline{0,17 \pm 0,01}$ & \multirow{2}{*}{0,18} & $\underline{0,15 \pm 0,02}$ & $\underline{0,15 \pm 0,02}$ & $\underline{0,17 \pm 0,03}$ & $\underline{0,19 \pm 0,01}$ \\
\hline & $0,13-0,21$ & $0,15-0,19$ & & $0,12-0,20$ & $0,12-0,18$ & $0,13-0,20$ & $0,18-0,22$ \\
\hline ппп & $\underline{10,74 \pm 1,11}$ & $\underline{18,92 \pm 7,93}$ & \multirow{2}{*}{11,60} & $\underline{15,40 \pm 1,60}$ & $\underline{12,78 \pm 1,86}$ & $\underline{15,70 \pm 2,05}$ & $\underline{11,43 \pm 1,14}$ \\
\hline & $8,60-12,30$ & $\overline{13,70-30,40}$ & & $\overline{13,00-18,10}$ & $9,50-15,40$ & $\overline{12,50-17,40}$ & $9,80-12,60$ \\
\hline $\mathrm{n}$ & 8 & 6 & 2 & 8 & 10 & 6 & 6 \\
\hline
\end{tabular}

Примечание. Здесь и далее: $\mathrm{n}$ - число проанализированных образцов. ${ }^{\#}$ - среднее арифметическое. В числителе - среднее арифметическое и стандартное отклонение, в знаменателе - минимальное и максимальное содержания. 
Таблица 2. Средние, минимальные и максимальные содержания редких и рассеянных элементов в алевритоглинистых породах нижней перми

\begin{tabular}{|c|c|c|c|c|c|c|c|c|}
\hline \multirow{5}{*}{$\begin{array}{c}\text { Компоненты, } \\
\text { г/т }\end{array}$} & \multicolumn{8}{|c|}{ Впадины } \\
\hline & \multicolumn{2}{|c|}{ Юрюзано-Сылвинская } & \multirow{2}{*}{$\begin{array}{c}\text { Бельская } \\
\text { р. Белая }\end{array}$} & \multirow{2}{*}{$\begin{array}{c}\text { Юрюзано- } \\
\text { Сылвинская } \\
\text { р. Уфа } \\
\end{array}$} & \multirow{2}{*}{$\begin{array}{c}\text { Бельская } \\
\text { р. Белая }\end{array}$} & \multicolumn{3}{|c|}{ Юрюзано-Сылвинская } \\
\hline & р. Юрюзань & р. Уфа & & & & p. $\mathbf{y}$ & & \multirow{3}{*}{$\frac{\text { р. Уфа }}{\text { Кунгурский ярус }}$} \\
\hline & \multirow{2}{*}{\multicolumn{2}{|c|}{ Ассельский ярус }} & \multirow{2}{*}{\multicolumn{2}{|c|}{ Сакмарский ярус }} & \multicolumn{3}{|c|}{ Артинский ярус } & \\
\hline & & & & & & Нижняя часть & Верхняя часть & \\
\hline \multirow{2}{*}{$\mathrm{Li}$} & $\underline{52.23 \pm 6.09}$ & $25.41 \pm 13.33$ & & $33.32 \pm 11.15$ & $\underline{48.87 \pm 6.12}$ & $\underline{29.43 \pm 3,73}$ & $\underline{43.81 \pm 11,40}$ & $66.63 \pm 19.07$ \\
\hline & $48.06-65.29$ & $10.70-43.64$ & 62.66 & $9.12-45.40$ & $40.93-57.66$ & $24.99-34.76$ & $28.78-64.70$ & $47.05-99.66$ \\
\hline \multirow{2}{*}{$\mathrm{Sc}$} & $\underline{19.84 \pm 4.00}$ & $\underline{24.83 \pm 9.56}$ & & $\underline{25.19 \pm 8.10}$ & $\underline{15.52 \pm 3.08}$ & $\underline{22.73 \pm 3,89}$ & $\underline{20.21 \pm 4,66}$ & $\underline{23.31 \pm 5.48}$ \\
\hline & $\overline{14.37-27.46}$ & $\overline{11.88-35.55}$ & 19.10 & $\overline{6.53-34.81}$ & $\overline{11.51-20.02}$ & $\overline{16.49-28.58}$ & $\overline{13.78-27.83}$ & $\overline{15.48-32.46}$ \\
\hline \multirow{2}{*}{$\mathrm{V}$} & $\underline{167.33 \pm 19.96}$ & $\underline{132.95 \pm 53.84}$ & & $\underline{127.04 \pm 37.56}$ & $\underline{138.32 \pm 22.54}$ & $\underline{125.88 \pm 16,76}$ & $\underline{165.70 \pm 32,50}$ & $\underline{157.55 \pm 13.67}$ \\
\hline & $136.23-198.38$ & $62.52-182.45$ & 144.82 & $38.13-163.51$ & $114.46-171.18$ & $95.90-153.44$ & $126.52-231.45$ & $133.92-171.63$ \\
\hline \multirow{2}{*}{$\mathrm{Cr}$} & $\underline{219.39 \pm 14.03}$ & $\underline{76.96 \pm 40.65}$ & & $\underline{137.62 \pm 48.78}$ & $\underline{245.44 \pm 75.73}$ & $\underline{105.60 \pm 18,16}$ & $\underline{120.55 \pm 24,65}$ & $\underline{117.01 \pm 26.28}$ \\
\hline & $197.36-235.36$ & $31.05-148.69$ & 311.30 & $\overline{30.63-189.43}$ & $132.95-378.57$ & $\overline{78.79-128.07}$ & $89.04-162.50$ & $\overline{84.41-160.85}$ \\
\hline \multirow{2}{*}{ Co } & $\underline{27.69 \pm 4.59}$ & $\underline{18.38 \pm 6.11}$ & 3318 & $\underline{17.64 \pm 7.36}$ & $\underline{31.41 \pm 6.81}$ & $\underline{15.73 \pm 3,81}$ & $\underline{20.75 \pm 3,67}$ & $\underline{18.29 \pm 3.01}$ \\
\hline & $20.76-35.31$ & $\overline{9.82-25.50}$ & 33.18 & $\overline{4.41-28.41}$ & $\overline{23.51-44.48}$ & $\overline{9.78-21.96}$ & $\overline{15.99-28.01}$ & $\overline{14.40-23.65}$ \\
\hline \multirow{2}{*}{$\mathrm{Ni}$} & $233.54 \pm 34.83$ & $49.41 \pm 23.95$ & 27111 & $\underline{79.04 \pm 30.60}$ & $\underline{280.37 \pm 104.59}$ & $\underline{80.14 \pm 13,03}$ & $\underline{86.74 \pm 17,46}$ & $\underline{89.95 \pm 11.80}$ \\
\hline & $178.40-281.94$ & $\overline{23.28-74.40}$ & 271.11 & $\overline{18.76-110.04}$ & $\overline{143.93-485.73}$ & $\overline{56.45-97.53}$ & $\overline{58.16-120.86}$ & $80.12-114.40$ \\
\hline \multirow{2}{*}{$\mathrm{Cu}$} & $\underline{70.92 \pm 16.37}$ & $\underline{69.79 \pm 35.29}$ & & $\underline{60.31 \pm 18.55}$ & $\underline{56.46 \pm 19.28}$ & $\underline{62.23 \pm 9,87}$ & $\underline{71.82 \pm 11,18}$ & $\underline{71.26 \pm 14.95}$ \\
\hline & $\overline{51.97-93.67}$ & $\overline{26.92-103.34}$ & 59.45 & $\overline{18.26-81.95}$ & $\overline{20.62-81.58}$ & $\overline{45.05-78.31}$ & $\overline{54.31-95.18}$ & $\overline{48.44-85.71}$ \\
\hline \multirow{2}{*}{$\mathrm{Zn}$} & $\underline{77.56 \pm 7.89}$ & $\underline{58.03 \pm 29.28}$ & & $\underline{51.30 \pm 15.94}$ & $\underline{75.17 \pm 36.75}$ & $\underline{51.98 \pm 26,48}$ & $\underline{70.80 \pm 18,65}$ & $\underline{43.90 \pm 9.91}$ \\
\hline & $\overline{68.67-92.77}$ & $\overline{24.03-89.18}$ & 99.04 & $\overline{13.67-63.90}$ & $\overline{43.81-160.03}$ & $\overline{28.79-123.27}$ & $\overline{48.00-106.36}$ & $\overline{33.49-63.01}$ \\
\hline \multirow{2}{*}{$\mathrm{Ga}$} & $\underline{14.48 \pm 1.41}$ & $\underline{9.79 \pm 4.00}$ & & $\underline{10.66 \pm 3.17}$ & $\underline{12.49 \pm 2.12}$ & $\underline{11.32 \pm 1,63}$ & $\underline{15.80 \pm 1,85}$ & $\underline{15.54 \pm 0.87}$ \\
\hline & $\overline{12.54-16.50}$ & $\overline{4.77-13.53}$ & 12.94 & $\overline{3.09-13.07}$ & $\overline{9.62-16.55}$ & $\overline{9.42-15.05}$ & $\overline{13.27-19.81}$ & $\overline{14.50-17.09}$ \\
\hline \multirow{2}{*}{$\mathrm{Rb}$} & $\underline{68.30 \pm 10.37}$ & $\underline{30.49 \pm 14.71}$ & 6054 & $\underline{44.16 \pm 13.55}$ & $\underline{60.25 \pm 7.86}$ & $\underline{48.67 \pm 9,81}$ & $\underline{59.34 \pm 11,73}$ & $\underline{53.56 \pm 2.96}$ \\
\hline & $51.23-79.51$ & $14.76-44.56$ & 00.54 & $12.81-54.95$ & $\overline{48.84-71.41}$ & $38.32-68.83$ & $36.59-84.57$ & $48.55-57.05$ \\
\hline \multirow{2}{*}{$\mathrm{Sr}$} & $129.89 \pm 32.78$ & $\underline{309.78 \pm 109.84}$ & 113.27 & $\underline{197.76 \pm 68.85}$ & $\underline{169.06 \pm 42.93}$ & $\underline{210.33 \pm 33,12}$ & $\underline{216.26 \pm 51,94}$ & $\underline{186.62 \pm 34.27}$ \\
\hline & $88.19-184.08$ & $141.95-476.81$ & 113.21 & $62.49-267.36$ & $\overline{106.78-231.24}$ & $\overline{172.5-286.74}$ & $150.95-288.17$ & $144.25-232.14$ \\
\hline \multirow{2}{*}{ Y } & $\underline{15.59 \pm 2.32}$ & $\underline{20.35 \pm 4.77}$ & & $\underline{17.99 \pm 5.20}$ & $\underline{13.73 \pm 0.93}$ & $\underline{21.19 \pm 3,76}$ & $\underline{16.94 \pm 2,84}$ & $\underline{16.98 \pm 4.23}$ \\
\hline & $\overline{13.21-20.22}$ & $\overline{13.58-24.98}$ & 13.16 & $\overline{5.44-21.57}$ & $\overline{12.68-15.29}$ & $\overline{16.32-30.95}$ & $\overline{13.03-22.13}$ & $\overline{11.00-22.71}$ \\
\hline \multirow{2}{*}{$\mathrm{Zr}$} & $\underline{87.05 \pm 8.70}$ & $\underline{47.70 \pm 20.87}$ & & $\underline{61.80 \pm 19.12}$ & $\underline{73.01 \pm 9.59}$ & $\underline{62.47 \pm 11,98}$ & $\underline{85.61 \pm 10,35}$ & $\underline{86.39 \pm 10.43}$ \\
\hline & $\overline{75.96-100.39}$ & $22.29-70.85$ & 86.85 & $15.95-74.93$ & $57.29-87.18$ & $\overline{51.37-90.42}$ & $72.69-105.35$ & $74.58-98.55$ \\
\hline \multirow{2}{*}{$\mathrm{Nb}$} & $\underline{9.44 \pm 0.92}$ & $\underline{3.48 \pm 1.54}$ & 764 & $\underline{4.60 \pm 1.44}$ & $\underline{6.55 \pm 1.02}$ & $\underline{4.35 \pm 0,70}$ & $\underline{5.58 \pm 0,83}$ & $\underline{5.40 \pm 0.44}$ \\
\hline & $\overline{8.53-11.14}$ & $1.64-5.05$ & 1.04 & $\overline{1.18-5.71}$ & $\overline{5.39-8.27}$ & $\overline{3.63-5.96}$ & $\overline{4.39-7.40}$ & $\overline{4.86-5.96}$ \\
\hline Mo & $\underline{0.89 \pm 0.43}$ & $\underline{1.78 \pm 2.08}$ & 194 & $\underline{1.33 \pm 0.70}$ & $\underline{2.16 \pm 0.77}$ & $\underline{1.04 \pm 0,27}$ & $\underline{0.76 \pm 0,71}$ & $\underline{1.93 \pm 1.79}$ \\
\hline MO & $0.48-1.68$ & $0.22-5.69$ & 1.94 & $0.23-2.28$ & $1.50-3.92$ & $0.56-1.56$ & $0.20-3.03$ & $0.37-5.16$ \\
\hline Sn & $1.45 \pm 0.32$ & $\underline{0.65 \pm 0.29}$ & 106 & $\underline{1.26 \pm 1.18}$ & $\underline{1.19 \pm 0.30}$ & $\underline{0.92 \pm 0,24}$ & $\underline{1.04 \pm 0,28}$ & $\underline{1.04 \pm 0.16}$ \\
\hline $\mathrm{Sn}$ & $\overline{1.06-1.91}$ & $\overline{0.33-0.97}$ & 1.06 & $\overline{0.21-4.09}$ & $\overline{0.91-1.86}$ & $\overline{0.72-1.50}$ & $\overline{0.73-1.76}$ & $\overline{0.78-1.28}$ \\
\hline & $\underline{3.88 \pm 0.78}$ & $2.60 \pm 1.62$ & & $2.88 \pm 0.91$ & $3.16 \pm 0.72$ & $\underline{3.30 \pm 1,09}$ & $2.75 \pm 0,61$ & $2.65 \pm 0.51$ \\
\hline $\mathrm{Cs}$ & $2.83-4.87$ & $0.91-5.73$ & 2.74 & $0.75-3.49$ & $1.90-4.29$ & $2.21-5.81$ & $1.83-3.77$ & $1.59-3.16$ \\
\hline
\end{tabular}


Окончание табл. 2

\begin{tabular}{|c|c|c|c|c|c|c|c|c|}
\hline D & $232.61 \pm 117.30$ & $178.16 \pm 70.41$ & 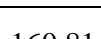 & $235.31 \pm 141.64$ & $275.73 \pm 320.82$ & $214.64 \pm 41,38$ & $249.68 \pm 28,52$ & $277.92 \pm 41.48$ \\
\hline $\mathrm{Ba}$ & $\overline{133.86-479.89}$ & $\overline{62.60-254.77}$ & 160.81 & $\overline{58.20-504.96}$ & $126.24-1063.83$ & $171.84-279.4$ & $196.61-305.30$ & $229.14-361.86$ \\
\hline $\mathrm{Ia}$ & $\underline{18.38 \pm 2.74}$ & $17.96 \pm 3.54$ & 1278 & $\underline{16.95 \pm 5.06}$ & $14.37 \pm 1.67$ & $\underline{23.25 \pm 5,08}$ & $15.71 \pm 3,76$ & $17.86 \pm 4.80$ \\
\hline & $\overline{14.53-20.94}$ & $12.69-22.28$ & 12.18 & $\overline{4.69-20.48}$ & $\overline{10.97-16.00}$ & $\overline{16.51-32.34}$ & $\overline{10.27-25.44}$ & $\overline{11.22-23.43}$ \\
\hline $\mathrm{Ce}$ & $\frac{38.22 \pm 4.37}{32.29-43.62}$ & $\frac{36.72 \pm 10.15}{24.30-48.56}$ & 28.51 & $\frac{33.79 \pm 10.11}{9.19-40.43}$ & $\frac{30.50 \pm 2.73}{2474-3326}$ & $\frac{45.53 \pm 10,97}{3161-66.04}$ & $\frac{32.41 \pm 7,18}{2155-4038}$ & $\frac{35.21 \pm 8.87}{2.61-46.11}$ \\
\hline $\operatorname{Pr}$ & $\frac{4.54 \pm 0.49}{3.93-5.17}$ & $\frac{4.65 \pm 1.34}{2.80-6.06}$ & 3.61 & $\frac{4.47 \pm 1.33}{1.24-5.27}$ & $\frac{3.71 \pm 0.30}{3.09-4.03}$ & $\frac{5.85 \pm 1,28}{4.43-8.56}$ & $\frac{4.19 \pm 0,73}{294-5.92}$ & $\frac{4.40 \pm 1.06}{288-5.54}$ \\
\hline $\mathrm{Nd}$ & $\frac{17.90 \pm 1.93}{15.63-21.26}$ & $\frac{20.04 \pm 5.71}{12.08-26.33}$ & 14.25 & $\frac{18.52 \pm 5.46}{5.26-22.08}$ & $\frac{14.72 \pm 0.91}{13.48-15.81}$ & $\frac{23.95 \pm 5,00}{18.54-34.55}$ & $\frac{17.57 \pm 2,97}{12.65-23.57}$ & $\frac{18.34 \pm 4.24}{11.97-23.21}$ \\
\hline $\mathrm{Sm}$ & $\frac{3.61 \pm 0.46}{3.12-4.43}$ & $\frac{4.46 \pm 1.40}{2.52-5.97}$ & 3.03 & $\frac{4.02 \pm 1.22}{1.11-4.91}$ & $\frac{3.04 \pm 0.17}{2.83-3.30}$ & $\frac{5.07 \pm 1,05}{4.06-7.38}$ & $\frac{3.80 \pm 0,58}{3.00-4.91}$ & $\frac{3.92 \pm 0.89}{2.56-4.97}$ \\
\hline $\mathrm{Eu}$ & $\frac{0.92 \pm 0.11}{0.84-1.15}$ & $\frac{1.30 \pm 0.40}{0.71-1.77}$ & 0.86 & $\frac{1.09 \pm 0.33}{0.31-1.37}$ & $\frac{0.81 \pm 0.05}{0.73-0.86}$ & $\frac{1.36 \pm 0,27}{1.05-1.95}$ & $\frac{1.05 \pm 0,15}{0.86-1.33}$ & $\frac{1.07 \pm 0.23}{0.75-1.33}$ \\
\hline Gd & $\frac{3.83 \pm 0.44}{3.07-4.29}$ & $\frac{4.45 \pm 1.34}{2.67-6.00}$ & 3.59 & $\frac{3.82 \pm 1.18}{1.06-4.86}$ & $\frac{3.02 \pm 0.55}{2.46-3.79}$ & $\frac{4.74 \pm 0,97}{3.83-6.75}$ & $\frac{3.58 \pm 0,56}{2.89-4.39}$ & $\frac{3.78 \pm 0.72}{2.95-4.76}$ \\
\hline $\mathrm{Tb}$ & $\frac{0.51 \pm 0.07}{0.45-0.66}$ & $\frac{0.65 \pm 0.20}{0.39-0.86}$ & 0.46 & $\frac{0.58 \pm 0.18}{0.16-0.72}$ & $\frac{0.42 \pm 0.02}{0.39-0.46}$ & $\frac{0.68 \pm 0,13}{0.55-0.95}$ & $\frac{0.53 \pm 0,09}{0.41-0.70}$ & $\frac{0.55 \pm 0.12}{0.38-0.71}$ \\
\hline Dy & $\frac{3.18 \pm 0.42}{2.82-4.09}$ & $\frac{4.14 \pm 1.31}{2.46-5.58}$ & 2.83 & $\frac{3.73 \pm 1.13}{1.03-4.62}$ & $\frac{2.66 \pm 0.17}{2.39-2.87}$ & $\frac{4.35 \pm 0,74}{3.65-5.94}$ & $\frac{3.34 \pm 0,56}{2.66-4.39}$ & $\frac{3.57 \pm 0.83}{2.31-4.58}$ \\
\hline Ho & $\frac{0.65 \pm 0.08}{0.58-0.84}$ & $\frac{0.85 \pm 0.26}{0.53-1.16}$ & 0.58 & $\frac{0.78 \pm 0.24}{0.21-0.98}$ & $\frac{0.55 \pm 0.03}{0.50-0.60}$ & $\frac{0.89 \pm 0,14}{0.73-1.19}$ & $\frac{0.69 \pm 0,12}{0.54-0.96}$ & $\frac{0.75 \pm 0.18}{0.51-0.99}$ \\
\hline $\mathrm{Er}$ & $\frac{1.94 \pm 0.29}{1.69-2.57}$ & $\frac{2.53 \pm 0.82}{1.56-3.57}$ & 1.79 & $\frac{2.34 \pm 0.72}{0.63-2.82}$ & $\frac{1.60 \pm 0.12}{1.40-1.79}$ & $\frac{2.63 \pm 0,42}{2.14-3.55}$ & $\frac{2.07 \pm 0,40}{1.52-2.83}$ & $\frac{2.30 \pm 0.56}{1.49-3.13}$ \\
\hline $\mathrm{Tm}$ & $\frac{0.28 \pm 0.04}{0.24-0.37}$ & $\frac{0.36 \pm 0.12}{0.21-0.51}$ & 0.26 & $\frac{0.34 \pm 0.11}{0.09-0.41}$ & $\frac{0.23 \pm 0.02}{0.20-0.25}$ & $\frac{0.39 \pm 0,06}{0.32-0.50}$ & $\frac{0.30 \pm 0,06}{0.21-0.43}$ & $\frac{0.35 \pm 0.09}{0.22-0.46}$ \\
\hline $\mathrm{Yb}$ & $\frac{1.88 \pm 0.22}{1.72-2.38}$ & $\frac{2.35 \pm 0.76}{1.47-3.19}$ & 1.77 & $\frac{2.27 \pm 0.69}{0.60-2.70}$ & $\frac{1.54 \pm 0.13}{1.34-1.75}$ & $\frac{2.51 \pm 0,36}{2.06-3.13}$ & $\frac{1.97 \pm 0,42}{1.42-2.77}$ & $\frac{2.30 \pm 0.62}{1.51-3.20}$ \\
\hline $\mathrm{Lu}$ & $\frac{0.29 \pm 0.04}{0.24-0.38}$ & $\frac{0.35 \pm 0.12}{0.22-0.52}$ & 0.26 & $\frac{0.34 \pm 0.11}{0.09-0.41}$ & $\frac{0.23 \pm 0.02}{0.20-0.26}$ & $\frac{0.39 \pm 0,06}{0.31-0.49}$ & $\frac{0.30 \pm 0,07}{0.22-0.45}$ & $\frac{0.35 \pm 0.10}{0.23-0.49}$ \\
\hline $\mathrm{Hf}$ & $\frac{2.67 \pm 0.25}{2.37-3.04}$ & $\frac{1.61 \pm 0.75}{0.77-2.55}$ & 2.76 & $\frac{2.07 \pm 0.64}{0.61-2.72}$ & $\frac{2.15 \pm 0.24}{1.86-2.56}$ & $\frac{2.05 \pm 0,41}{1.51-2.75}$ & $\frac{2.59 \pm 0,38}{2.10-3.34}$ & $\frac{2.85 \pm 0.24}{2.52-3.15}$ \\
\hline $\mathrm{Pb}$ & $\frac{6.86 \pm 1.39}{4.97-8.36}$ & $\frac{4.91 \pm 2.31}{2.40-7.42}$ & 10.58 & $\frac{7.37 \pm 4.31}{1.46-16.86}$ & $\frac{10.21 \pm 3.33}{7.66-17.94}$ & $\frac{7.36 \pm 1,61}{5.34-9.65}$ & $\frac{7.82 \pm 2,36}{3.71-11.51}$ & $\frac{9.68 \pm 4.41}{4.95-15.88}$ \\
\hline $\mathrm{Bi}$ & $\frac{0.14 \pm 0.02}{0.12-0.16}$ & $\frac{0.06 \pm 0.04}{0.02-0.10}$ & 0.10 & $\frac{0.08 \pm 0.03}{0.01-0.11}$ & $\frac{0.11 \pm 0.02}{0.09-0.14}$ & $\frac{0.11 \pm 0,03}{0.075-0.15}$ & $\frac{0.11 \pm 0,07}{0.045-0.14}$ & $\frac{0.12 \pm 0.02}{0.09-0.16}$ \\
\hline Th & $\frac{5.13 \pm 0.53}{4.35-5.75}$ & $\frac{3.43 \pm 1.80}{1.27-5.44}$ & 4.30 & $\frac{4.66 \pm 1.51}{1.12-6.18}$ & $\frac{3.87 \pm 0.41}{3.42-4.49}$ & $\frac{5.38 \pm 1,13}{3.83-7.37}$ & $\frac{4.16 \pm 1,11}{3.78-735}$ & $\frac{5.71 \pm 1.46}{3.96-7.67}$ \\
\hline $\mathrm{U}$ & $\frac{2.29 \pm 0.27}{1.83-2.68}$ & $\frac{1.46 \pm 0.60}{0.67-2.16}$ & 1.90 & $\frac{1.57 \pm 0.49}{0.40-2.00}$ & $\frac{1.87 \pm 0.22}{1.56-2.24}$ & $\frac{1.98 \pm 0,44}{1.46-2.75}$ & $\frac{1.70 \pm 0,34}{1.25-2.26}$ & $\frac{2.06 \pm 0.36}{1.76-2.63}$ \\
\hline $\mathrm{n}$ & 7 & 7 & 1 & 8 & 8 & 11 & 14 & 7 \\
\hline
\end{tabular}


Песчаники ассельского яруса на широте р. Юрюзани представлены кварцевыми граувакками (кварца 30-35\%), зерен полевых шпатов здесь совсем немного, но соотношение обломков пород приблизительно такое же, как и на широте р. Уфы. В разрезе по р. Белой содержание основных породообразующих компонентов в песчаниках сакмарского и артинского возрастов приблизительно такое же, как в кунгурских - по Уфе, но среди обломков пород заметно меньше зерен вулканитов (особенно основного состава).

Среди глинистых минералов в составе алевритоглинистых пород, по данным рентгенофазового анализа, везде преобладают смешанослойные (хлоритмонтмориллонит) разности. В разрезах по p. Уфе иногда встречаются хлорит и гидрослюды - до 5-10\%. По р. Белой доля хлоритов и гидрослюд более высокая, содержание их сопоставимо с таковым смешанослойных минералов. Во всех глинистых породах, как и в песчаниках, присутствует изменчивое количество вторичных карбонатов (преимущественно кальцита), иногда до 40-50\% и более.

По данным химического состава ${ }^{1}$ (табл. 1), ассоциации глинистых минералов в рассматриваемых породах, однако, несколько другие. Так, на диаграмме

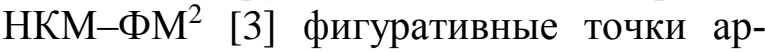
гиллитов с р. Белой сосредоточены в основном в полях II (преимущественно монтмориллонитовые глины с примесью каолинита и гидрослюды), IV (хлоритгидрослюдистые глины) и VI (гидрослюдистые глины со значительной примесью дисперсных полевых шпатов) (рис. 2, а). Данное сообщество описывается значениями НКМ и ФМ, соответственно 0.22-0.51 и 0.14-0.40. Глинистые породы ЮрюзаноСылвинской впадины (разрезы по р. Уфе)

\footnotetext{
1 Все дальнейшие рассуждения построены нами именно на этих данных без пересчета на бескарбонатный состав или ту или иную минимизацию доли карбонатов кальция и магния, входящих в состав цемента и некоторого количества обломков карбонатного состава.

2 Здесь $\mathrm{HKM} \mathrm{=}\left(\mathrm{Na}_{2} \mathrm{O}+\mathrm{K}_{2} \mathrm{O}\right) / \mathrm{Al}_{2} \mathrm{O}_{3}, \Phi \mathrm{M}=$ $\left(\mathrm{Fe}_{2} \mathrm{O}_{3}+\mathrm{MgO}\right) / \mathrm{SiO}_{2}$.
}

на этой же диаграмме локализованы преимущественно в полях IV (хлоритгидрослюдистые глины) и V (хлоритсмектит-гидрослюдистые глины) (см. рис. 2, б), а сообщество фигуративных точек определяется значениями НКМ и ФМ 0.26-0.45 и 0.14-0.30, т.е. оно несколько более компактно, нежели область составов пород Бельской впадины.

Расположение точек составов аргиллитов на классификационной диаграмме $\mathrm{TiO}_{2}-\mathrm{TM}^{3}$ [3] приблизительно такое же, как и на диаграмме НКМ-ФМ. Фигуративные точки пород всех разрезов локализуются в основном в поле 2 (существенно гидрослюдистые глины), значения $\mathrm{TiO}_{2}$ и ТМ находятся в интервале соответственно 0.40-0.80 и 0.04-0.07 (рис. 3). Несогласованность данных рентгенофазового и термического анализов с рассчитанными значениями геохимических модулей, скорее всего, определяется присутствием в аргиллитах значительного объема смешанослойных минералов.

Сопоставление валовых химических составов алевритоглинистых пород нижней перми со средним постархейским австралийским глинистым сланцем (PAAS, [2]) показывает, что по содержаниям таких оксидов, как $\mathrm{SiO}_{2}, \mathrm{TiO}_{2}, \mathrm{Al}_{2} \mathrm{O}_{3}, \mathrm{FeO}_{\text {общ, }}$ $\mathrm{K}_{2} \mathrm{O}$ и $\mathrm{P}_{2} \mathrm{O}_{5}$, они достаточно похожи (рис. 4). Основные же отличия наблюдаются в содержаниях оксидов магния и кальция, в меньшей степени - натрия. Причем, особенно высокой является концентрация $\mathrm{CaO}$ и $\mathrm{MgO}$ в аргиллитах ассельского и сакмарского ярусов ЮрюзаноСылвинской впадины.

Анализ приведенных в табл. 1 данных позволяет видеть, что средние содержания ряда оксидов на отдельных стратиграфических уровнях, с учетом величин стандартных отклонений, вполне сопоставимы. Исключением являются только $\mathrm{SiO}_{2}$, $\mathrm{CaO}$ и, в какой-то мере, $\mathrm{Al}_{2} \mathrm{O}_{3}$ (рис. 5). Так, среднее количество оксида кремния в породах ассельского яруса в разрезе по р. Юрюзани более чем на 10\% превосходит

\footnotetext{
${ }^{3}$ Здесь $\mathrm{TM}=\mathrm{TiO}_{2} / \mathrm{Al}_{2} \mathrm{O}_{3}$.
} 
его содержание в ассельских же аргиллитах из бассейна р. Уфы. Кроме того, для $\mathrm{SiO}_{2}$ характерно постепенное увеличение средней концентрации вверх по разрезу. Особенно хорошо это видно на профиле по р. Уфе. В то же время количество $\mathrm{CaO}$ в глинистых породах этого же профиля уменьшается по направлению от ассель- ского к кунгурскому ярусу. Вверх по разрезу растет и среднее содержание $\mathrm{Al}_{2} \mathrm{O}_{3}$, хотя и не так заметно, как, например, $\mathrm{SiO}_{2}$ (см. рис. 5). На юге, по р. Белой, тенденции несколько иные. Там средняя концентрация $\mathrm{Al}_{2} \mathrm{O}_{3}$ в аргиллитах уменьшается от сакмарского к артинскому ярусу, а $\mathrm{CaO}$, наоборот, увеличивается.

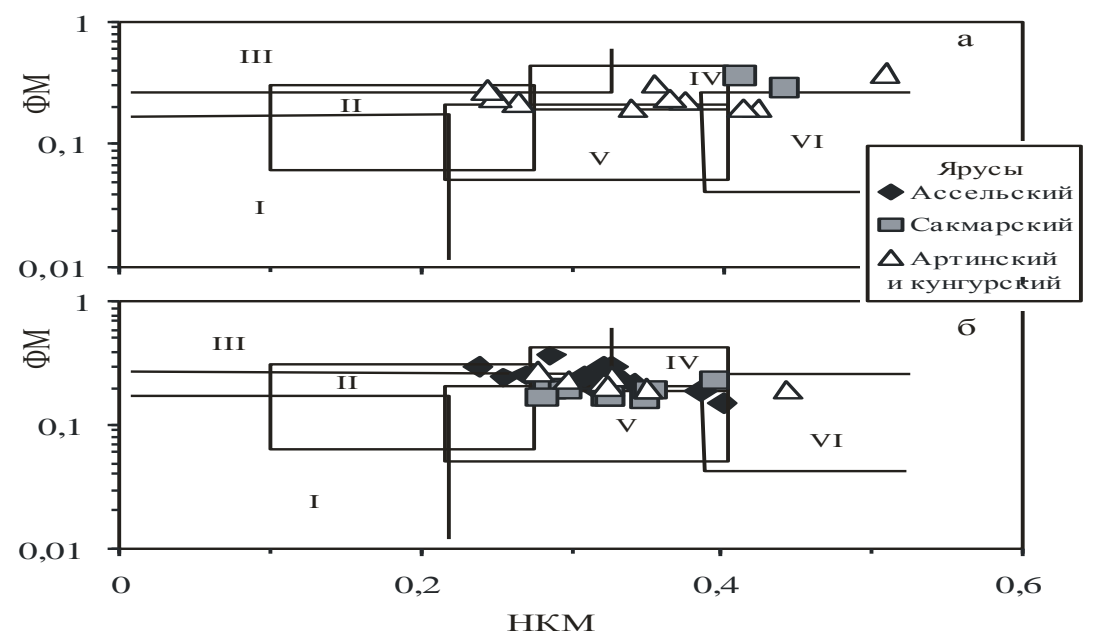

Рис. 2. Положение точек состава тонкозернистых обломочных пород нижней перми Бельской (а) и Юрюзано-Сылвинской (б) впадин Предуральского прогиба на диаграмме НКМ-ФМ. Поля глинистых пород: I - преимущественно каолинитовых; II - преимущественно монтмориллонитовых с примесью каолинита и гидрослюды; III - преимущественно хлоритовых с примесью $F е$-гидрослюд; IV-хлорит-гидрослюдистых; $V$-хлорит-смектит-гидрослюдистых; VI-гидрослюдистых со значительной примесью дисперсных полевых шпатов

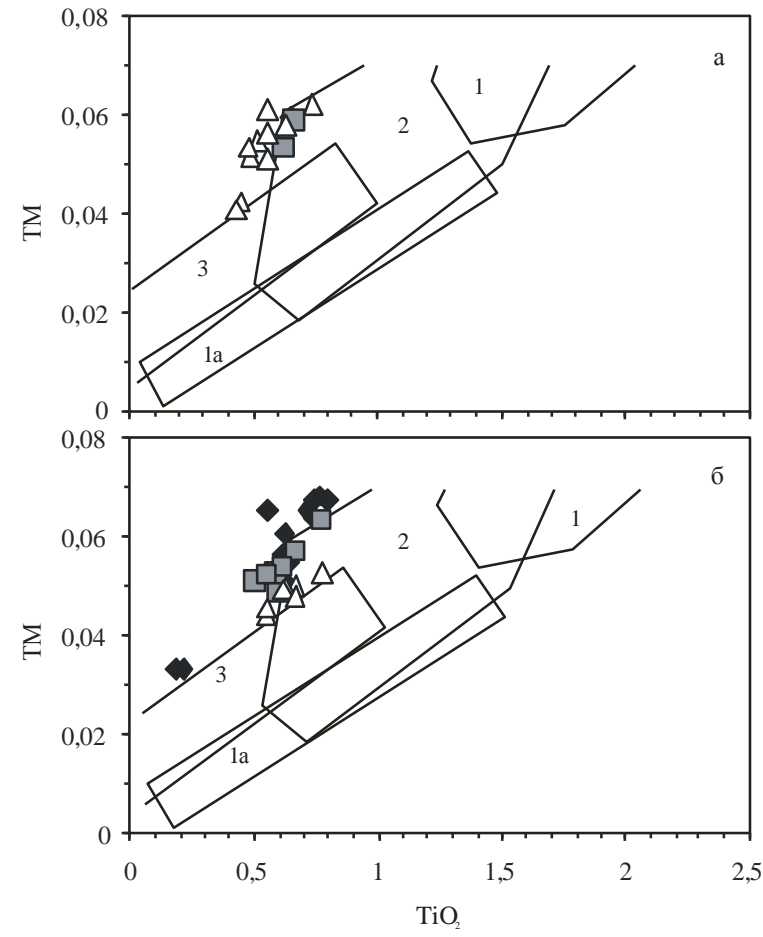

Рис. 3. Положение фигуративных точек состава тонкозернистых обломочных пород нижней перми Бельской (а) и Юрюзано-Сылвинской (б) впадин на диаграмме $\mathrm{TiO}_{2}-\mathrm{TM}$. Условные обозначения см. на рис. 2. Глины: 1 - каолинитовые; 19 - низкомодульные каолинитовые - продукты катагенетических преобразований смектитового или каолинитового субстрата; 2 - существенно гидрослюдистые; 3 - существенно смектитовые 

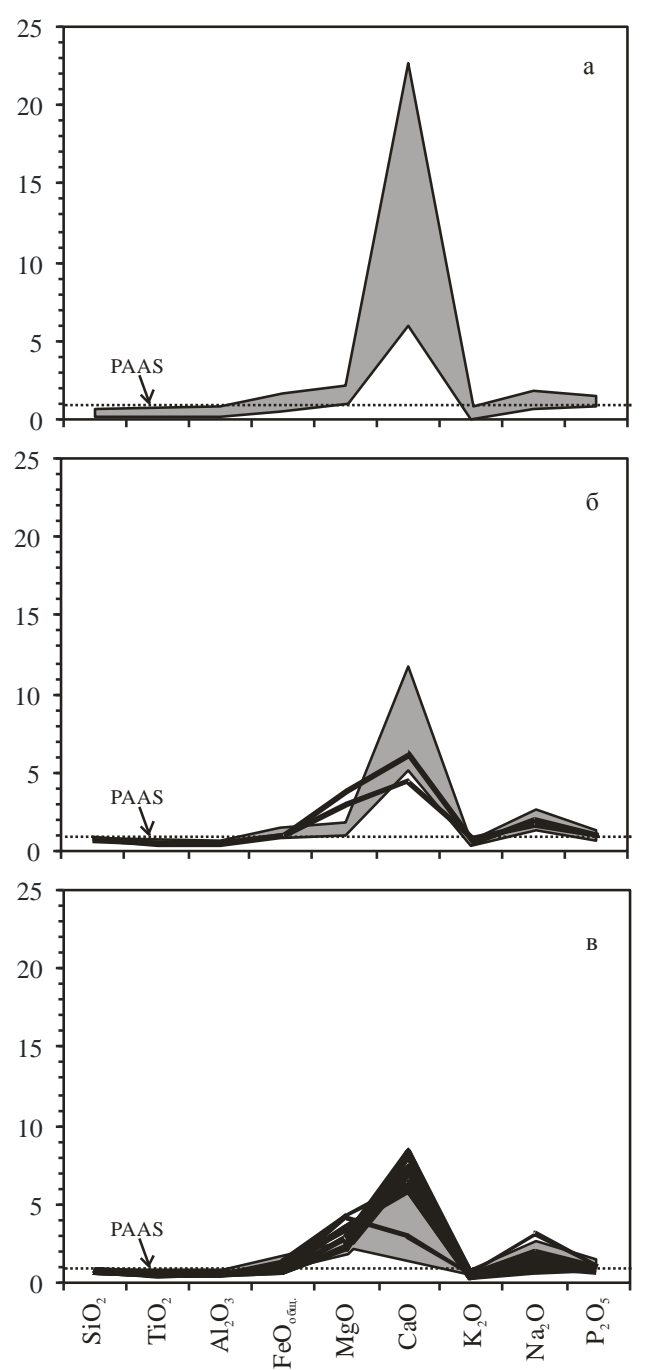

Рис. 4. Нормированные на PAAS содержания основных породообразующих оксидов в аргиллитах и алевритистых аргиллитах Бельской (сплошнье линии) и ЮрюзаноСылвинской (серый фон) впадин Предуральского прогиба. Ярусы: $a$ - ассельский; $б$ сакмарский; в - артинский и кунгурский

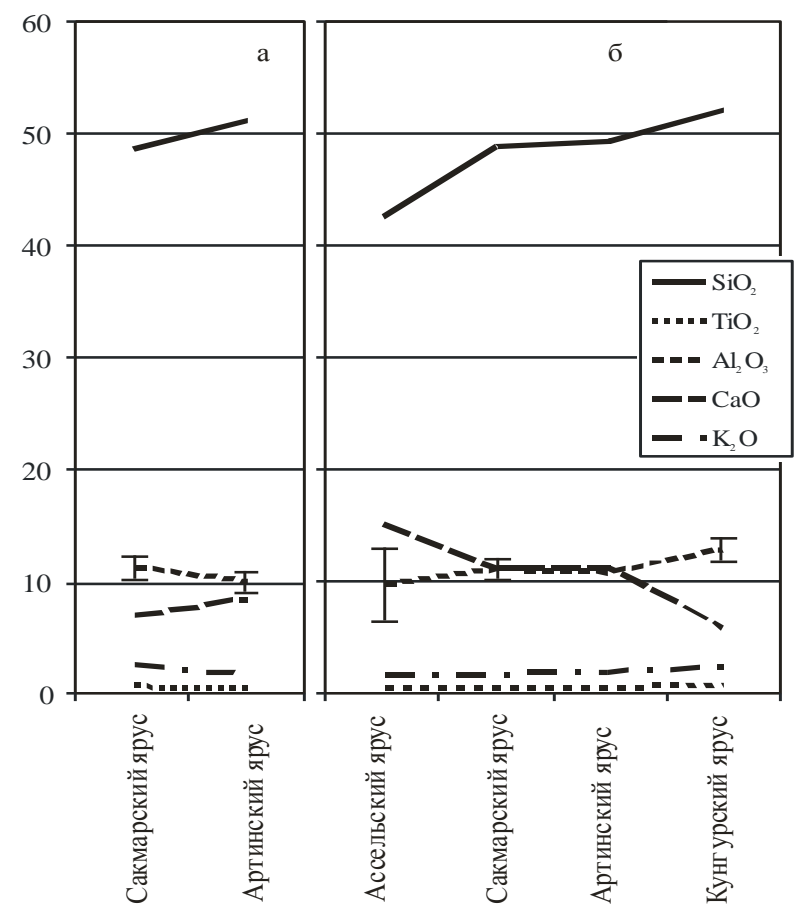

Рис. 5. Изменение средних содержании ряда породообразуюших оксидов в аргиллитах и алевритистых аргиллиmax в разрезах по $\mathrm{pp}$. Белой (а) и Уфе (б). Для $\mathrm{Al}_{2} \mathrm{O}_{3}$ показаны также величинь стандартных отклонений 

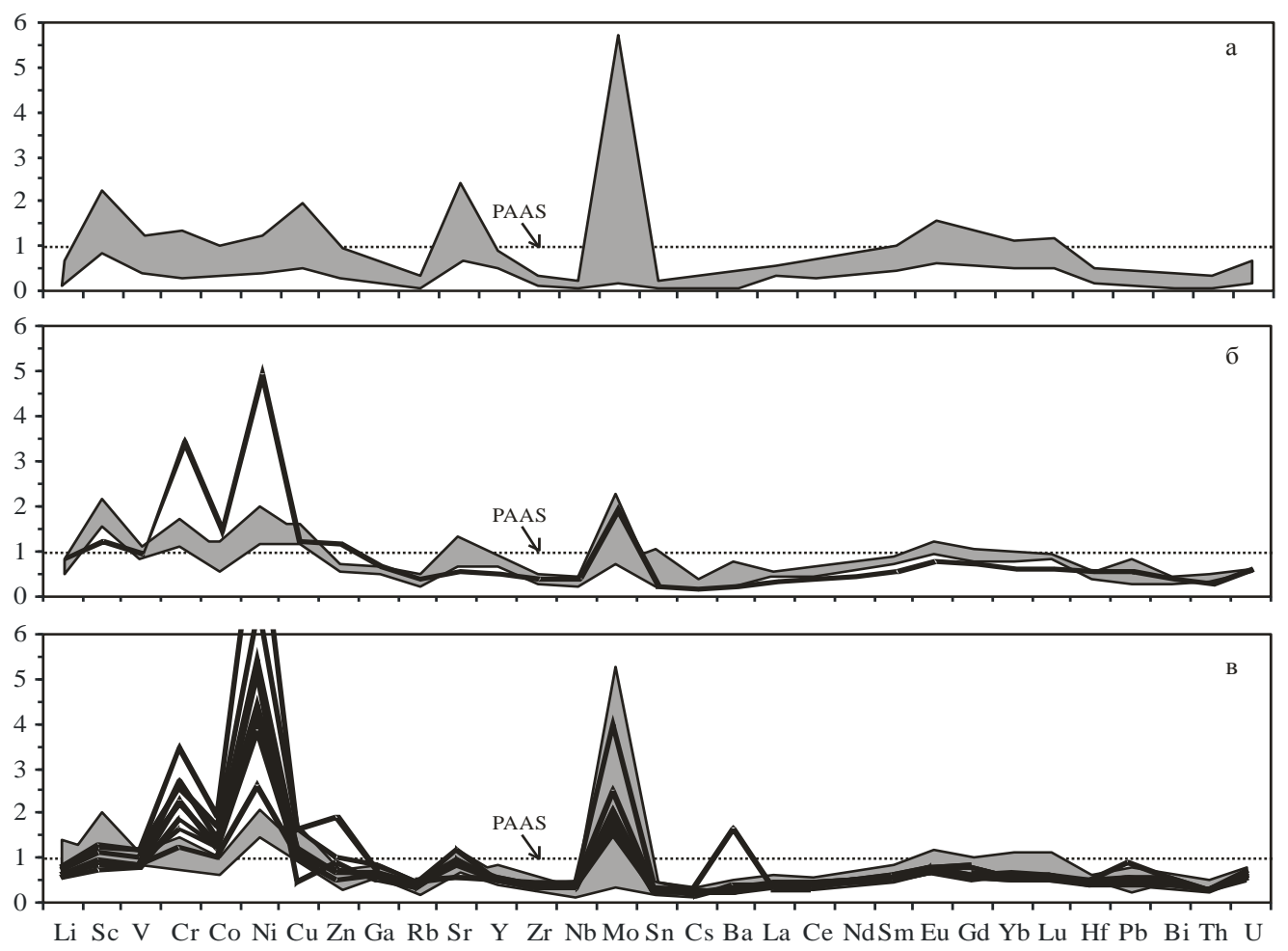

Рис. 6. Нормированные на PAAS содержания ряда редких и рассеянных элементов в глинистых породах Бельской (сплошные линии) и Юрюзано-Сылвинской (серый фон) впадин. Ярусы: : $а$ ассельский; б - сакмарский; в- артинский и кунгурский

Данные о средних содержаниях и пределах вариаций редких и рассеянных элементов приведены в табл. 2. Эти же сведения использованы для нормирования на содержание указанных элементов в PAAS (рис. 6). Анализ графиков показывает, что в глинистых образованиях ассельского яруса на юге Юрюзано-Сылвинской впадины содержания $\mathrm{Cr}$, Cо и $\mathrm{Ni}$ в подавляющем большинстве проб выше, чем на $p$. Уфе. В то же время в последних выше содержания $\mathrm{Sr}$ и Мо. Концентрации остальных микроэлементов в породах обоих профилей достаточно близки, но в целом ниже, чем в PAAS. Средние значения $\mathrm{C}_{\text {проба/ }}$ С РАAS в породах данного стратиграфического уровня на р. Юрюзани составляют для $\mathrm{Sc}, \mathrm{V}, \mathrm{Cr}, \mathrm{Co}, \mathrm{Ni}$ и $\mathrm{Cu}$ соответственно $1.24 \pm 0.25,1.12 \pm 0.13,1.99 \pm 0.13$, $1.20 \pm 0.20,4.25 \pm 0.63$ и $1.42 \pm 0.33$; на широте p. Уфы - $1.55 \pm 0.50, \quad 0.89 \pm 0.36$, $0.70 \pm 0.37, \quad 0,80 \pm 0.27, \quad 0.90 \pm 0.44 \quad$ и $1.40 \pm 0.71$.
Сакмарский ярус Бельской врадины представлен в нашей выборке только одной пробой, поэтому все сказанное далее относительно сопоставления геохимического облика глинистых пород данного стратиграфического интервала носит сугубо предварительный характер. Исходя из имеющихся в нашем распоряжении данных в аргиллитах Бельской впадины концентрации $\mathrm{Cr}$, Co и $\mathrm{Ni}$, а также $\mathrm{Zn}$ более высокие, чем Юрюзано-Сылвинской, тогда как содержания $\mathrm{Sc}, \mathrm{Sr}, \mathrm{Y}$ и ряда редкоземельных элементов (РЗЭ) несколько ниже. По отношению к PAAS содержания большинства редких и рассеянных элементов в породах данного стратиграфического уровня, как и в асселе, ниже; только для $\mathrm{Sc}, \mathrm{Cr}, \mathrm{Co}, \mathrm{Ni}, \mathrm{Cu}$ и $\mathrm{Zn}$ значения $\mathrm{C}_{\text {про- }}$ ба /СРАа составляют соответственно 1.19 , $3.43,1.44,4.93,1.19$ и 1.17.

Глинистые породы артинского яруса Бельской впадины также содержат повышенные, относительно PAAS и пород Юрюзано-Сылвинской впадины, концен- 
трации хрома, кобальта и никеля (средние значения $\mathrm{C}_{\text {проба }} / \mathrm{C}_{\text {PAAS }}$ для них соответственно составляют $2.23 \pm 0.69,1.37 \pm 0.30$ и $5.10 \pm 1.90)$. Высокие значения Мо характерны как для пород Бельской, так и Юрюзано-Сылвинской впадин $(2.16 \pm 0.77$ от PAAS). Среднее содержание $\mathrm{Cu}$ часто также несколько повышено - $1.13 \pm 0.39$ от уровня PAAS.

Содержание РЗЭ в алевритоглинистых породах сакмарского яруса Бельской впадины составляет 74.60 г/т, артинского яруса $-77.39 \pm 5.88$ г/т. Это примерно в 2 раза меньше, чем сумма РЗЭ в PAAS, и связано, по всей видимости, как с разубоживающим влиянием вторичного кальцита, так и с заметным количеством примеси алевритовых зерен кварца. В глинистых образованиях ЮрюзаноСылвинской впадины сумма РЗЭ варьирует от $100.81 \pm 27.25$ (ассельский уровень) до 93.05 \pm 27.65 г/т (сакмарский ярус).
Величина $(\mathrm{La} / \mathrm{Yb})$ PAAS для аргиллитов сакмарского яруса Бельской впадины составляет 0.52 , а для аналогичных пород артинского яруса $-0.67 \pm 0.11$. Приблизительно такой же в среднем рассматриваемый параметр характерен для глинистых образований Юрюзано-Сылвинской впадины. Так, для ассельского яруса он составляет $0.57 \pm 0.09$ (р. Уфа) и $0.68 \pm 0.10$ (р. Юрюзань), для аргиллитов сакмарского яруса $-0.53 \pm 0.05$. Средние значения отношения $(\mathrm{Gd} / \mathrm{Yb})_{\text {PAAs в породах Юрюза- }}$ но-Сылвинской впадины варьируют от 0.97 до 1.11, в породах Бельской впадины - от 1.14 до 1.19. Европиевая аномалия в глинистых породах нижней перми Бельской впадины относительно PAAS положительная (1.17-1.26); в породах Юрюзано-Сылвинской - её значения меняются от 1.30 до 1.38 .

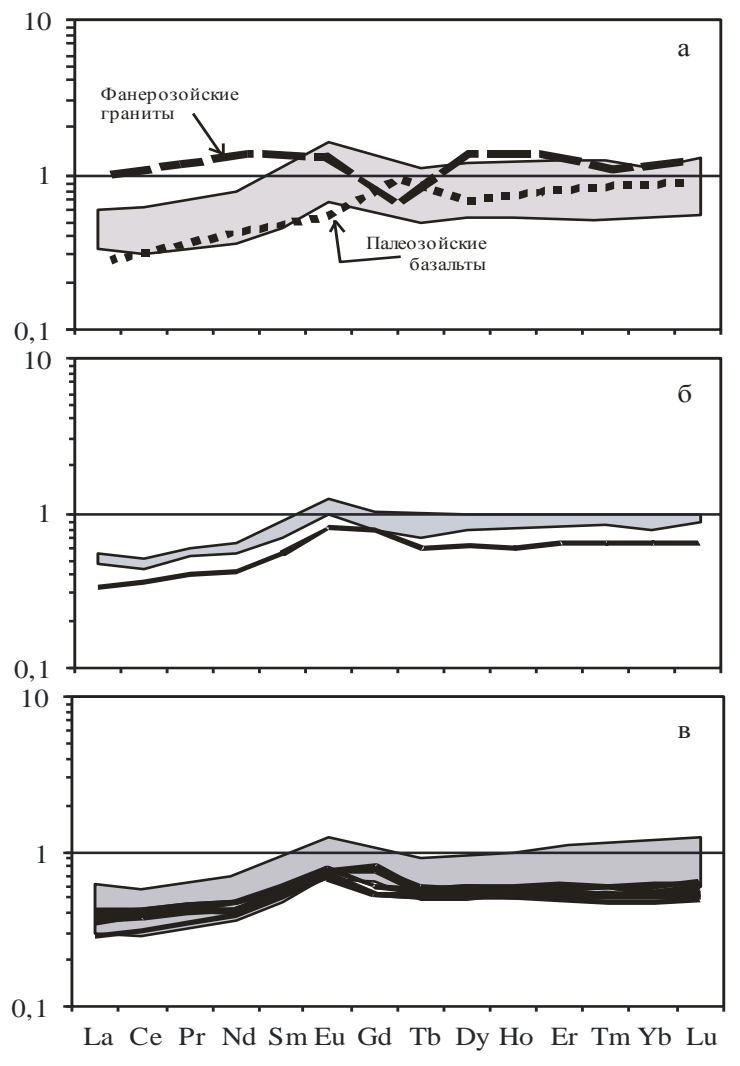

Рис. 7. Нормированные на PAAS спектры распределения редкоземельных элементов в аргиллитах Бельской (сплошные линии) и Юрюзано-Сылвинской (серый фон) впадин Предуральского прогиба. Ярусы: $a$ - ассельский; $б$ - сакмарский; в - артинский и кунгурский. Спектры РЗЭ в палеозойских гранитах и базальтах построень по даннымм [4] 

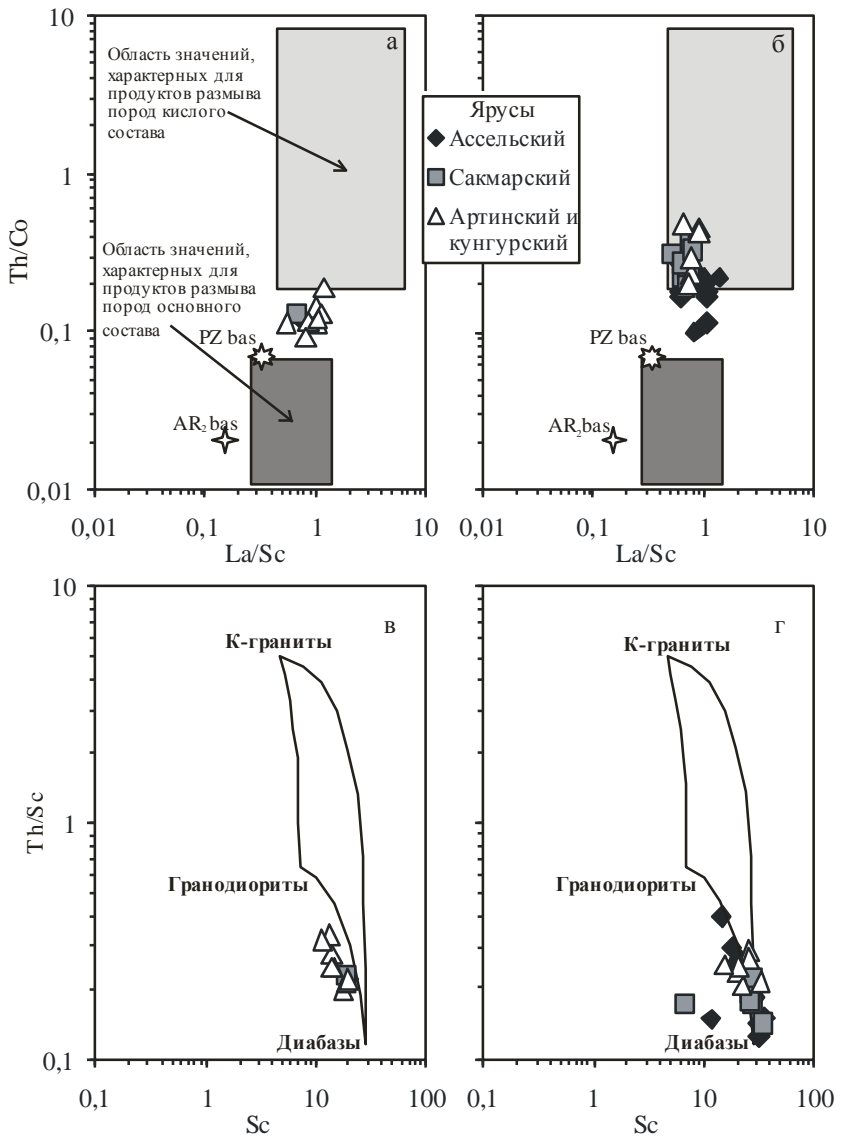

Рис. 8. Положение фигуративных точек состава глинистых пород нижней перми Бельской $(a$, в) и Юрюзано-Сылвинской (б, г) впадин Предуральского прогиба на диаграммах $\mathrm{La} / \mathrm{Sc}-\mathrm{Th} / \mathrm{Co} \quad$ u $\mathrm{Sc}-\mathrm{Th} / \mathrm{Sc}$. Средние точки составов верхнеархейских (AR2 bas) u палеозойских (PZ bas) базальтов по [4]. Условные обозначения см. на puc. 2.
Таким образом, спектры распределения нормированных на PAAS редкоземельных элементов в аргиллитах обеих впадин Предуральского прогиба, сопоставимы (рис. 7). Исходя из общих особенностей (выраженная обедненность легкими лантаноидами, небольшая положительная $\mathrm{Eu}$ аномалия, отсутствие обогащения тяжелыми элементами) можно видеть, что они весьма близки к нормированному на PAAS спектру распределения РЗЭ в палеозойских базальтах [4]. На существенную роль пород основного состава на палеоводосборах раннепермского возраста указывает и положение фигуративных точек составов на диаграммах $\mathrm{La} / \mathrm{Sc}-\mathrm{Th} / \mathrm{Co}$ [5] и $\mathrm{Sc}-\mathrm{Th} / \mathrm{Sc}$ [2] (рис. 8).

Анализ полученных данных по литогеохимии глинистых пород всех ярусов нижней перми свидетельствует об отсутствии принципиальных различий между Бельской и Юрюзано-Сылвинской впадинами Предуральского прогиба. Несмотря на пространственную разобщенность (в том числе во время осадконакопления), их основные геохимические характеристики вполне сопоставимы, что может свидетельствовать об общем источнике сноса. В целом валовый химический состав глинистых пород нижней перми Предуральского прогиба сопоставим с PAAS по содержаниям $\mathrm{SiO}_{2}, \mathrm{TiO}_{2}, \mathrm{Al}_{2} \mathrm{O}_{3}, \mathrm{FeO}_{\text {общ, }} \mathrm{K}_{2} \mathrm{O}$ и $\mathrm{P}_{2} \mathrm{O}_{5}$, некоторое отличие наблюдается лишь по $\mathrm{MgO}, \mathrm{CaO}$ и $\mathrm{Na}_{2} \mathrm{O}$. В то же время тенденции в колебаниях средних содержаний основных породообразующих оксидов от ассельского яруса к кунгурскому в той и другой впадине прогиба несколько различны. В Юрюзано-Сылвинской (профиль по р. Уфе) наблюдается увеличение вверх по разрезу содержаний $\mathrm{SiO}_{2}, \mathrm{TiO}_{2}$, $\mathrm{Al}_{2} \mathrm{O}_{3}, \mathrm{~K}_{2} \mathrm{O}$, в то время как концентрация $\mathrm{CaO}$ в этом направлении уменьшается. Средние содержания $\mathrm{FeO}_{\text {общ }}, \mathrm{MgO}, \mathrm{Na}_{2} \mathrm{O}$ и $\mathrm{P}_{2} \mathrm{O}_{5}$ изменчивые. В Бельской впадине концентрация большинства оксидов от 
сакмарского к артинскому ярусу уменьшается. Не укладывается в эту закономерность только $\mathrm{SiO}_{2}, \mathrm{CaO}$ и $\mathrm{MnO}$. Содержания $\mathrm{Cr}, \mathrm{Co}, \mathrm{Ni}$ и $\mathrm{Zn}$ в большинстве образцов аргиллитов Бельской впадины выше, чем в Юрюзано-Сылвинской, в то же время для аргиллитов р. Уфы характерны несколько более высокие концентрации Sc, Sr, Y, Мо и РЗЭ. Распределение РЗЭ в аргиллитах обеих впадин сопоставимо. Общая обедненность их, относительно PAAS, легкими лантаноидами, а также слабо выраженная положительная $\mathrm{Eu}$ аномалия предполагают присутствие в составе пород существенной доли продуктов размыва основных магматических образований. На это же указывают значения такого индикаторного отношения, как $\mathrm{La} / \mathrm{Sc}$, и содержания Sc.

Авторы выражают признательность Н.С. Глушковой за помощь в подготовке иллюстративного материала, а также Н.П. Горбуновой, Л.А. Татариновой, Г.С. Неупокоевой, В.П. Власову, Д.В. Киселевой, Н.Н. Адамович, Н.В. Чередниченко,
О.А. Березиковой и Л.К. Дерюгиной за выполнение аналитических работ.

Исследования выполнены при финансовой поддержке проекта УрО РАН 12-С-5-

1014.

\section{Библиографический список}

1. Мизенс Г.А. Об этапах формирования Предуральского прогиба // Геотектоника. 1997. № 5. C. 33-46.

2. Тейлор С.P., МакЛеннан С.М. Континентальная кора: ее состав и эволюция. М.: Мир, 1988.384 с.

3. Юдович Я.Э., Кетрис М.П. Основы литохимии. СПб.: Наука, 2000. 479 с.

4. Condie K.C. Chemical composition and evolution of the upper continental crust: contrasting results from surface samples and shales // Chem. Geol. 1993. Vol. 104. P. 137.

5. Cullers R.L. Implications of elemental concentrations for provenance, redox conditions, and metamorphic studies of shales and limestones near Pueblo, CO, USA // Ibid. 2002. Vol. 191. P. 305-327.

\title{
To Comparison of Bulk Chemical Composition of Lower Permian Clay Rocks (Uruzano-Sylvinskaya and Belsk Depression)
}

\author{
G.A. Mizens, A.V. Maslov \\ Institute of Geology and Geochemistry, Urals Branch of RAS, \\ 620075, Ekaterinburg, Pochtovyi per., 7. E-mails: mizens@igg.uran.ru, \\ maslov@igg.uran.ru
}

Analysis of the lithogeochemical characteristics of the Lower Permian clay rocks from Belsk and Uruzano-Sylvinskaya depressions of the PreUralian foredeep indicates that there are no principal differences between them, which may indicate the presence of a single source of deposited material. Bulk chemical composition of the Lower Permian clay rocks is comparable to PAAS content of $\mathrm{SiO}_{2}, \mathrm{TiO}_{2}, \mathrm{Al}_{2} \mathrm{O}_{3}$, $\mathrm{FeO}_{\text {tot }}, \mathrm{K}_{2} \mathrm{O}$ and $\mathrm{P}_{2} \mathrm{O}_{5}$. A difference of composition is observed only in $\mathrm{MgO}, \mathrm{CaO}$ and $\mathrm{Na}_{2} \mathrm{O}$. Content of $\mathrm{Cr}, \mathrm{Co}, \mathrm{Ni}$, and $\mathrm{Zn}$ in most mudstone from Belsk depression is higher than in Uruzano-Sylvinskaya depression. Simultaneously, mudstone from the basin of Ufa River has slightly higher concentrations of Sc, Sr, Y, Mo and REE. Distribution of REE in mudstone of the two basins is comparable. Their general depletion by light lanthanides in comparison with PAAS, and a low positive Eu anomaly 
suggest the presence a substantial portion of the products of erosion of the basic magmatic complexes in the clay rocks.

Key words: Uruzano-Sylvenskaya depression, Belsk depression, clay rocks, Lower Permian, bulk chemical composition.

\section{References}

1. Mizens G.A., 1997. Ob etapakh formirovaniya Preduralskogo progiba [About the stages of formation of the Pre-Urals foreland basin]. Geotektonika. 5:33-46.

2. Teylor S.R., McLennan S.M., 1988. Kontinentalnaya kora: eyo sostav I evolutsiya [The continental crust: Its composition and evolution]. Moscow, Mir, p. 384.
3. Yudovich Ya.E., Ketris M.P., 2000. Osnovy litokhimii [Basics of Lithochemistry]. St. Petersburg, Nauka, p. 479.

4. Condie K.C., 1993. Chemical composition and evolution of the upper continental crust: contrasting results from surface samples and shales. Chem. Geol., 104:1-37.

5. Cullers R.L., 2002. Implications of elemental concentrations for provenance, redox conditions, and metamorphic studies of shales and limestones near Pueblo, CO, USA. Chem. Geol., 191:305-327. 